\title{
Transportation Planning through GIS and Multicriteria Analysis: Case Study of Beijing and XiongAn
}

\author{
Asim Farooq $\mathbb{D}^{1},{ }^{1}$ Mowen Xie $\mathbb{D},{ }^{1}$ Svetla Stoilova, ${ }^{2}$ Firoz Ahmad, ${ }^{3}$ Meng Guo, ${ }^{4}$ \\ Edward J. Williams, ${ }^{5}$ Vimal Kr. Gahlot, ${ }^{6}$ Du Yan $\left({ }^{\circ},{ }^{7}\right.$ and Ahmat Mahamat Issa ${ }^{7}$ \\ ${ }^{1}$ School of Civil and Resource Engineering, University of Science and Technology, Beijing, China \\ ${ }^{2}$ Professor at Transportation Department, Technical University of Sofia, Bulgaria \\ ${ }^{3}$ Vindhyan Ecology and Natural History Foundation, Mirzapur, Uttar Pradesh, India \\ ${ }^{4}$ College of Architecture and Civil Engineering, Beijing University of Technology, China \\ ${ }^{5}$ Department of Engineering, University of Michigan, Dearborn, USA \\ ${ }^{6}$ Public Works Department, Bikaner, India \\ ${ }^{7}$ School of Civil and Resource Engineering, University of Science and Technology, China
}

Correspondence should be addressed to Asim Farooq; asimfarooq1234@gmail.com and Mowen Xie; mowenxie@ustb.edu.cn

Received 30 December 2017; Revised 27 April 2018; Accepted 17 July 2018; Published 18 October 2018

Academic Editor: Emanuele Crisostomi

Copyright (C) 2018 Asim Farooq et al. This is an open access article distributed under the Creative Commons Attribution License, which permits unrestricted use, distribution, and reproduction in any medium, provided the original work is properly cited.

Urban population growth and urbanization with its impact on urban planning require continuous research in order to address the challenges posed by transportation requirements. Identifying transportation capacity (road and railways) is an important task that can identify whether the network is capable of sustaining the present volume of traffic and whether it can handle the future intended traffic flow. A new city, XiongAn, will be built in the coming years in order to relieve the pressure of population on Beijing and disperse the economic growth, business activity, and opportunities across the country. The focus of this research is to generate a transportation model between Beijing and XiongAn, in order to increase connection and connectivity, reduce travel time, and increase transfer capacity between the two hubs (Beijing-XiongAn). The existing transportation network between two cities is analyzed and a network which can handle future demand has been proposed. The first stage has been the investigation of a variety of options using geographic information system (GIS). Planning and implementing a mass transit system requires choosing among options such as an existing intercity railway line, a new high-speed railway line, and/or motorway options. In the second phase of our analysis, we assess these options relative to multiple criteria, using the analytic hierarchy process (AHP). The options were evaluated using various criteria responsible for selection of alternative; it is found that travel time, cost of travel, safety, reliability, accessibility, and environment are key criteria for selecting the best alternative. The GIS and multicriteria analysis suggested that the best option is to build a new high speed railway line.

\section{Introduction}

The economic growth and urban development of any city depend on its transportation network. Transportation planning is a complex process involving careful forecasting of future needs and study of existing travel pattern in cities. Innovations in transportation planning and development have occurred and emerging challenges put pressure on developers and planners to update their toolkits [1]. They need to develop a more balanced view of accessibility [2] and mobility [3]. Expansion of the transit network and the consequent increase of human activity are a complex process which needs to be integrated with multipurpose land use and minimum effects on the environment [4-6]. Smart sustainable transportation awareness is increasing day by day; hence most planners agree that increased frequency and efficiency of transport options will play a key role in solving problems of congestion. Solving the problem in this way is a continuous long-term process whose impact will be visible only in the long term [7]. Many cities around the world are expanding and the demand for transportation is increasing, placing planners under great pressure [8]. Inadequate 
knowledge, unjustifiable assumptions in modeling, uncertainty regarding model validation, and lack of transparency have led to considerable skepticism with planning [1]. The lack of suitable integrated approaches strongly affects the quality and reduces the attractiveness of transit networks in developing countries [7]. Lack of robust transportation models, planning and traffic forecasting, inefficient land use and inefficient interfaces between different means of transportation, and inaccurate analysis of supply and demand are basic recurring problems in many developing countries [9]. Due to the different mindsets of transportation planners, many priorities such as cost-benefit analyses and environmental impact assessments remain unresolved and put the overall plan at serious risk [1].

1.1. Literature Review. China is leading the world in highspeed rail network capacity, with $16,000 \mathrm{~km}$ of track in service, annual passenger volume of 2,122,992 million, and annual freight volume of 40.99 billion tons [10]. The passenger has different preferences depending on distance and time [11]. The uncertainty of the time needed to travel by road has become a major concern from the perspective of the traveler, whose experience of the same trip varies from day to day [12-14]. In assessing rail capacity, it is possible to define the maximum number of trains that can pass a bottleneck section in a fixed period of time. The performance of any transportation system is limited by its own capacity [8, 15-17]; Chinese cities are still struggling with air pollution problems. A study found that from 2006 onwards rail transportation has been playing an integral part in environmental recovery and has had a significant positive impact in China [10].

Accessibility and connectivity are the most important parameters to consider in establishing an integrated transportation network in a city. The initial step is to analyze and understand the existing transportation network and seek to utilize resources more efficiently rather than just to extend the network [11]. The growth of the Chinese economy places the transportation system under pressure. The tension between increased demands for transport and constraints imposed by environmental protection increases the complexity of the overall transport problem [10]. Land use and passenger volume have a strong correlation in Beijing. The existence of places of interest and the likelihood that large numbers will wish to visit them are important factors to be considered by the urban planner and transportation planner [18]. Transit travel time reliability has become a very hot topic for research in recent decades due to congestion [19]. The best options for travel mode choice, travel time and distance, and safety and comfort are heavily dependent on Beijing passenger volume. The best options for travel mode choice, travel time and distance, and safety and comfort are heavily dependent on Beijing passenger volume [18]. Internal-combustion vehicles on roads emit much more pollution than trains using the railways. Therefore, the environmental cost of railways is markedly less than that of roadways [20]. In the United States, $15 \%-20 \%$ of the land is used by road networks; in China, the corresponding percentage is $19 \%[21,22]$.

Urbanization increases the number of automobiles and mileage of road usage and increases the pressure to invest more money in the autoindustry to increase GDP [23]. The rapid expansion of the road network is considered the major factor affecting sustainable development in China [24]. Urbanization is the catalyst in increasing automobile manufacturing, vehicle ownership, expansion of road network and social interaction [23]. Road network effects the social networking and interaction, while social life is widely affected by transportation facility available in the cities [25]. Many research studies have found that the expansion of road transportation results in the increase of vehicle ownership, energy use, and higher emission levels, increasing congestion, ever more complex and intrusive road networks, a vehiclebased society and inefficient usage of available resources [4, 26-32].

Every one percent increase in GDP for road transportation is responsible for an increase in energy consumption of 0.33 percent and 1.26 percent of urbanization [23]. Many research studies have found that the road network in Beijing is complex and dense, and continuous expansion in road infrastructure strongly affects the future development of the city along with increased motorization [4, 33, 34]. Road network structure (either single lane or multilane) strongly increases the ecological risk, need for more risk assessment, division, and interference in the regional forest landscape [33, 35-37]. The expansion of the road network has many adverse effects, such as separation effects, greater ecological risk, an increased level of air pollution, faster habitat destruction, and pedestrian safety $[4,38,39]$.

Various methods are available for route selection; a feasible route will be defined as one reducing the overall cost of transportation (operating cost, construction cost, minimum separation effects, and environmentally friendly) and increasing efficiency, (direct route, shortest travel distance, better accessibility, and mobility options) [40, 41]. The presence of many criteria is common to many areas of scientific research. In transport this method is used, for example, to determine the mode of transportation, to estimate the passenger satisfaction, and to evaluate the transport projects and for other purposes. Transportation planning and modeling with GIS have made analysis convenient and accessible; many real transportation problems can be analyzed, forecast, and simulated with GIS [42]. Launching transportation applications in GIS has increased the usage of GIS for transportation planning and modeling in recent years; now it is referred to by the acronym GIS-T [43]. Technological improvement is continually progressing, and rapid development of geographic information system (GIS) of spatial information technology is now used more widely [44-46]. Studies have found that accessibility, transportation planning, transit network analysis, and social economic and environmental implications can be evaluated [47, 48]. GIS can be used to ascertain the "attraction nodes" (e.g., offices, tourist attractions, and hotels) within a broad area [49], and GIS applications pertinent to the field of transportation engineering were developed [50] to analyze the impact of activity trips on regional transportation patterns. Within GIS it is now possible to analyze, forecast, simulate, and implement an imaginary transportation model, expansion road network analysis, and regional road network design [51, 52]. 
High-speed rail transit can reinforce the links between cities, provide a reliable and attractive facility for the passenger, and increase the willingness to travel [53]. Furthermore, although the initial cost of rail transit is higher, the operating cost is lower, and there is the prospect of higher passenger comfort, higher safety, a dedicated system, and higher performance compared to other transportation modes (light rail and bus system) [54]. Rail transit can maximize transit ridership, achieve maximum operating speed and higher efficiency, be environmentally friendly, and increase the options open to the traveler by offering higher network efficiency, higher connectivity, and ease of transfer [55].

The multicriteria analysis allows assessing criteria and prioritizing alternatives for transport planning. GIS gives the opportunity to preset the real objects as transport networks on maps and to integrate network characteristics into data base. The integration of both methods could serve to make decisions of transport planning. The aim of this study is to investigate the criteria for transport planning and to elaborate methodology to choose the transportation between two cities-megapolis and satellite using GIS and multicriteria analysis. In sum, the development of a methodology for transport planning by applying both multicriteria analysis and GIS data analysis taking into account different economic, infrastructure, environmental, technological, and other factors has been insufficiently investigated. This paper offers an integrated approach to planning the transportation between two big cities by taking into account route analysis and multiple factors relevant for transport.

\section{Methodological Approach}

The research methodology comprises the following steps:

(i) Step 1: Identifying routes between cities using GIS and route analysis

(ii) Step 2. Defining criteria and prioritization of the routes using the multicriteria method

The methodology developed to prioritize the variant routes and the second step of methodology involves multicriteria analysis. The present research uses the Analytic Hierarchy Process (AHP), developed by Saaty in 1980 [56], which assesses the weight to be given to the various criteria and to prioritize the various routes according to their maximum AHP scores. The AHP method is based on the following principles: structure of the model; development of the ratings for each decision alternative for each criterion; synthesis of the priorities. The pairwise comparisons between each criterion and variant routes are performed using Saaty's scale, [57-59] (shown in Appendix Table 5).

\section{Case Study and Numerical Testing}

The Chinese capital Beijing is one of the world's most populated megacities. For this megacity, it is necessary to solve the problem of choosing a transport connection with the newly formed city satellite XiongAn. This research is a case study of the connection between Beijing and XiongAn. The populations of Beijing, Tianjin, and Hebei are 22 million,
15.5 million, and 74.3 million, respectively; and their annual growth rates have reached $16.2 \%, 14.4 \%$, and $11.6 \%$, respectively [60]. So there is a huge gap in the development of these three areas, and Hebei needs to sustain almost four times the population of Tianjin and Beijing. This helps explain why the current project is located in Hebei; it is hoped thereby to close the developmental gap by providing job opportunities and a boost to the local economy. XiongAn is planned to be built between the present counties of Xiong, Rongcheng, and Anxin, from which it obtains the name XiongAn. The newly developed area, also called jing-jin-ji, will connect Beijing, Tianjin, and Hebei and is designed to increase the economic activity and reduce the development distance between these 3 provinces.

Urbanization in China is at a peak, and most job opportunities are to be found in new urban areas [61]. XiongAn is a satellite town to accommodate the overburdened population of Beijing [62]. Many studies describe the current state of Beijing as "urban disease" or "urban ill" $[63,64]$. Beijing has decided to extend its municipal administration to the border with Tongzhou in Hebei province to reduce the population burden on the capital city [62]. The newly built XiongAn will provide population relief for the massive capital city [64]. With the continuous process of integration, Tianjin and Hebei will become more attractive places to work and live [64]. XiongAn is located in Hebei province, which connects the three counties of Xiong, Rongcheng, and Anxin, as shown in Figure 1. The name is derived from the two counties Xiong and Anxin which are XiongAn [65]. The initial developmental plan is for $100 \mathrm{~km}^{2}(100 \mathrm{~km}$ west of Tianjin and $100 \mathrm{~km}$ southwest of Beijing). After completing the initial development plan, the development will further extend for $200 \mathrm{~km}^{2}$ and there is long-term planning for $2000 \mathrm{~km}^{2}[63,66]$. XiongAn, located in the southwest of Beijing, is to serve as a developmental hub for Beijing, Tianjin, and Hebei, creating an economic triangle (Jing-JinJi) or jingjinji. Located in the Baoding area of Hebei province, it completes a triangle between Beijing, Tianjin, and Hebei [67].

Step 1 (identifying routes between cities using GIS and route analysis). According to "Urban Road Engineering Design Code" (cjj37-2012), roads in china are characterized as one of four types. Type 1 has a speed of $100-120 \mathrm{~km} / \mathrm{h}$ and typically has four lanes. Type 2 is trunk roads connecting the districts inside the city and consisting of four or more lanes in each direction with speeds of $40-60 \mathrm{~km} / \mathrm{h}$. Type 3 is secondary roads having two to four lanes with speeds of $30-50 \mathrm{~km} / \mathrm{h}$. Type 4 is branch two-lane roads (community roads) with speeds of $20-40 \mathrm{~km} / \mathrm{h}$. [68-70].

The Beijing transportation network is very complex and spreads across the entire city. GIS and Road network analytics suggests that available motorway in the direction of "XiongAn is the only available option. GIS data relating to motorways linking cities in China favored having a motorway route in the direction "XiongAn." In a case study for the first phase, we subdivide the area within the $50 \mathrm{~km}$ buffer, to determine how much road infrastructure and rail 

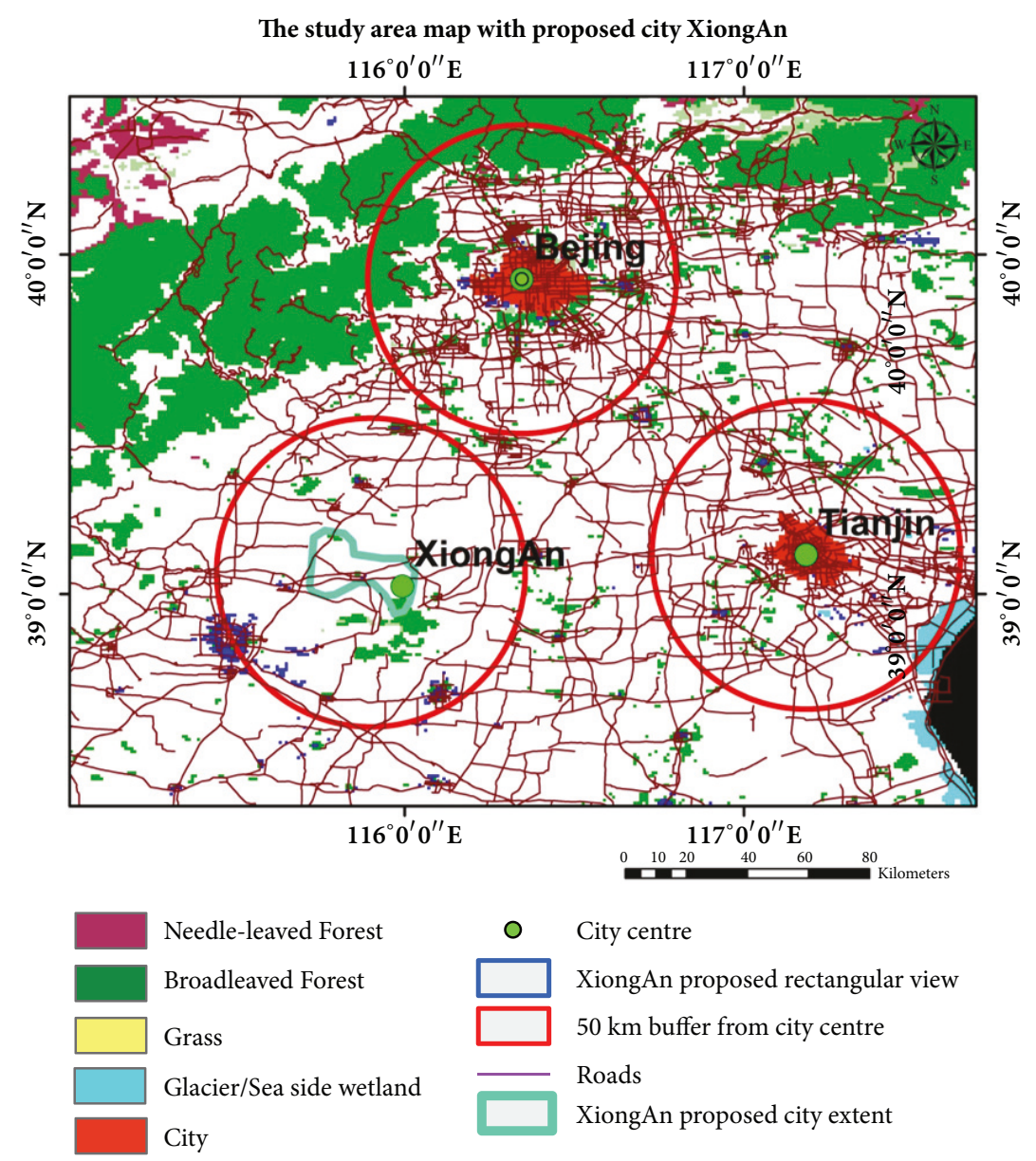

Figure 1: Beijing, Tianjin, and Hebei road network map.

infrastructure are available in the newly developed area as shown in Figure 1.

Using study area 1, as depicted in Figure 2, a shortroute analysis specifies the Beijing to XiongAn as $125 \mathrm{~km}$ by one route and $167 \mathrm{~km}$ by another route. A longer route is available from study area 2 via Tianjian and extends to $196 \mathrm{~km}$. The expected time in all these routes is more than two hours, as estimated from Baidu ditu and baidu map (which gives real time traffic analytics). The major part of the road consists of express highway where the speed is around $100 \mathrm{~km} / \mathrm{h}$, while the minor road portion is based on secondary and trunk roads, which mainly pass near residential districts in the city. This proportion of road consists of many intersections and crossings while the speed does not exceed $50 \mathrm{~km} / \mathrm{h}$.

For a detailed analysis, Beijing city is divided into 4 study areas as shown in Figure 2, to measure the road infrastructure from a specified area and to analyze the connection and connectivity within the cities and within the newly developed areas. According to Figure 2, the available road network is from "Study Area 1" while there is no connection between study areas 2, 3, and 4 . Within the short circular radius study area 2 and area 4 can be connected with study area 1 , but there is no connection between study areas 1 and 4 .
The current system has very weak connections and connectivity in study areas 2,4 , and especially study area 3. Xiongan is located in the north of the city. There is no circular radial connection which gives a short and convenient route for people. Hence Beijing is already facing a higher number of vehicle, air pollution, and environmental problems. This study will propose the construction of a new road line from study area 3 , which also facilitates access to/from study areas 2 and 4 . Hence the burden from study area 1 will be reduced. The inhabitants of the capital city will have a fast, easy, and convenient route from Beijing to Xiongan. From short route analytics it is measured that the travelling time is two hours each way, and this may not attract many people to work or live there in future. Furthermore, the present research proposes a new road from study area 3 , along with a high-speed railroad. The existing road starts from Qianmen east road. Hence the two suggestions will increase the connection and connectivity between study area 3 and study area 1 . This case study suggests a route from the second ring road to Qianmen east road which will increase the connection between the two areas.

According to Figure 3, which represents the transportation route between Beijing and Tianjin, the minimum time needed (analysis from baidu ditu) when traveling by road is more than two hours depending on traffic conditions, and 


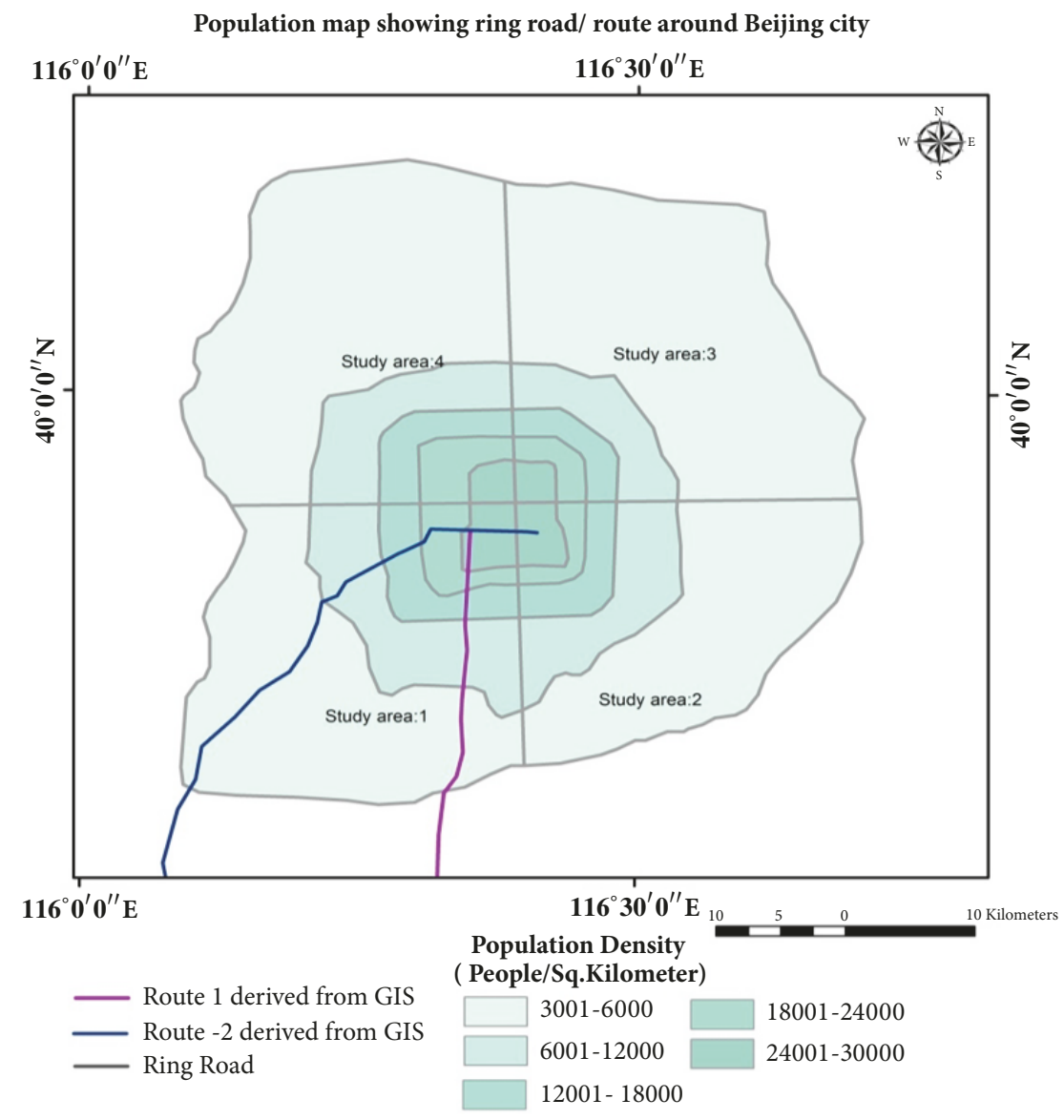

FIGURE 2: Distribution of Beijing city on the basis of population and ring road.

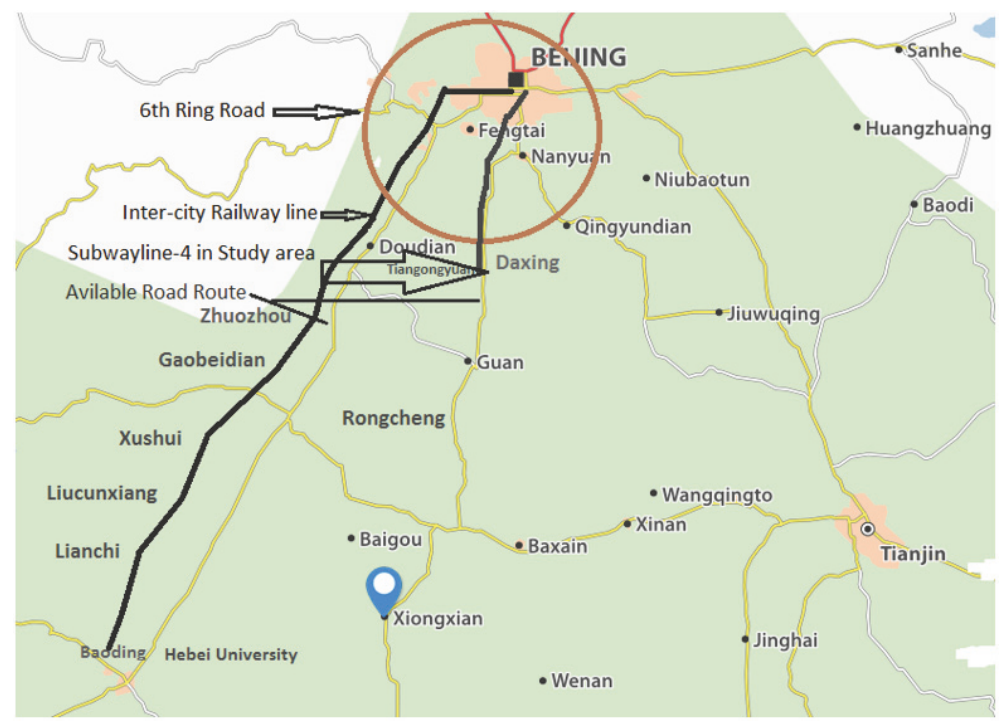

Figure 3: Beijing to Baoding Existing Transportation Network (near XiongAn).

with the intercity railway line according to GIS maps and the Beijing station chart the minimum distance to reach to Baoding the area near to Xiongan is more than three and a half hours, even four hours. A subway line which provides access from the second to the sixth ring road is also shown in the map; it is $26 \mathrm{~km}$ long and near the Daxing Area in the south of Beijing. There is no direct rail route between Beijing and Xiongan, and the distance between Baoding and Xiongan 
is around $55 \mathrm{~km}$, but the distance from "Xushui" is $40 \mathrm{~km}$ from the railway line of a tiny town in the same direction.

\section{Results and Discussion}

This study recommends the following research suggestions.

A radial railway line is proposed to connect the two cities to increase the connectivity, and to generate higher ridership, provide greater passenger convenience, reduce travel time, reduce traffic volume on parallel highways and meet passenger demand. From the Beijing second ring area in the direction "XiongAn", the available rail track length is $26 \mathrm{~km}$ at line 4 , of which the last stop is Tiangongyuan, which is located outside the 6 th ring road. Since road network links in Beijing are quite widespread and complex, it is now critical to reduce traffic congestion greatly due to these issues [34].

The study recommends a high-speed railway line connecting the two cities. In analysis from a survey using the subway application, GIS map and city short route application demonstrates that it takes more than one hour and twentyfive minutes to arrive at Tiangongyuan (last station at Line 4 ). So if the distance of $26 \mathrm{~km}$ is covered in one hour and twenty-six minutes on the only available subway line in that direction, the question arises: will it attract people to travel or make them willing to live in the newly developed area?

Another question is how to reach to the newly developing area in a way that is convenient and acceptable to passengers. The total distance between Beijing and XiongAn is around $130 \mathrm{~km}$. If this distance is covered within one hour, then most of the people will be willing to travel. Hence the usual travel time in Beijing from home to work is in between fortyfive minutes to one hour, plus time spent in transit network (Travel time) [71].

A high-speed radial line is needed, one station of which is located inside each of the $2 \mathrm{nd}, 3 \mathrm{rd}, 4 \mathrm{th}, 5^{\text {th }}$, and 6 th ring roads, and the last station lies in the newly built area "XiongAn." The new radial line will follow the major demand directions towards the newly built city. To meet required capacity the circle (beltway) Lines 2 and 10 will play a major role in the distribution of passengers across the city. Furthermore, these circle lines will be effective distributors for subway and bus lines; thereby enabling suburb-tosuburb trips to use a radial-circle-radial path. Connection and connectivity within each ring will increase passenger distribution across the city. The transfer from one line to another will be reduced through offering more connectivity through integrated transit planning. The high-speed railway line is the optimum solution to the case study. There is a huge road network, especially in Beijing. But due to problems such as traffic congestion, traffic jams, unhealthy air, higher $\mathrm{CO} 2$ content in the air, and many other environmental issues, the city seeks relief from all these problems [62]. This is the right time for the country to step up its sustainable development. To connect Beijing with "Xiongan," the city needs a regional fast speed railway line, which provides transportation between the two cities in less than 60 minutes $[72,73]$. Switzerland provides a model of how this can be done [74].
The sole purpose of suggesting the High speed railway line (HSRL) (Figure 4) between Beijing and Xiongan is to meet the future needs of inhabitants outside the city. The initial stage is to develop $50 \mathrm{~km}^{2}$ area but, in future, the planning can be applied to similar areas in the country. The proposed line for HSRL is shown in the map, where the stations are proposed in $2 \mathrm{nd}, 4 \mathrm{th}$, 5th, and 6 th ring roads, so the Beijing subway will work as feeder lines and buses as branch lines in the city.

4.1. Distributed Terminals Network Model for Beijing. The distributed terminals concept is to minimize the adverse impacts of Central and Directional Terminals and maximize the effectiveness and efficiency of public transportation. Many countries have the problem of a centrally based transportation network which increases the travel time and burden on the city centre. Every transit mode originates to and from the centre. For example, Munich (Germany) used a central terminal system, but because of a limited population of 1.5 million people $[75,76] 69 \%$ of Munich inhabitants use public transit modes [77], so it is only a problem at peak hours and functions effectively in offpeak hours [78, 79]. The set of terminals in this case essentially comprises existing and proposed metro rail connections through the city. Such network can provide more accessibility in the city, which is to transport the inhabitants between two cities in a mode in which they are willing to travel. This mode should offer more and ask for less (less transfer, higher connection through the city, ease of reaching the station). Distributed terminals will provide better access facilities to potential HSR passengers. They will also provide city managers with facilities to handle local and regional traffic more efficiently in future to increase connection and connectivity, reduce the number of transfers, offer direct trips, and increase comfort and convenience.

In the case study of Beijing (as shown in Figure 2), the city is located in the south of the city; hence as shown in Figure 5, we present the details to connect the new city with Beijing. For the Beijing case study it is assumed that each of the directional corridors will have three access nodes in the HUB area. For example, the corridor connecting the southern parts of the region or other regions in that direction will have its terminal at the northern end of the HUB area and two additional access nodes, one in the centre and the other at the southern end. Likewise, all the other corridors will have their terminals at the respective opposite ends of the hub area. Corridor 1, as shown in Figure 5 (C-1), connects Nodes A and $\mathrm{G}$ in the same region as Node $\mathrm{A}$ or another passes through Nodes B, C, and D in the hub area and Nodes E and F in the region. The terminal for Corridor C-1 is Node A. Nodes $A$ to $\mathrm{D}$ are the locations of existing or proposed terminal locations of transport services in the HUB area. Corridor C-2 connecting Node $\mathrm{H}$ in the region can be planned such that its terminal in the hub area is at Node C. Likewise Corridor C-3 may have its terminal in the hub area at Node B. Alternatively, Corridors C-2 and C-3 can have a common terminal at Node $\mathrm{B}$ or $\mathrm{C}$. Nodes $\mathrm{H}$ and I could be in different regions in their respective directions. Distributed terminals provide uniform accessibility throughout the city, combining directional and central terminals. 

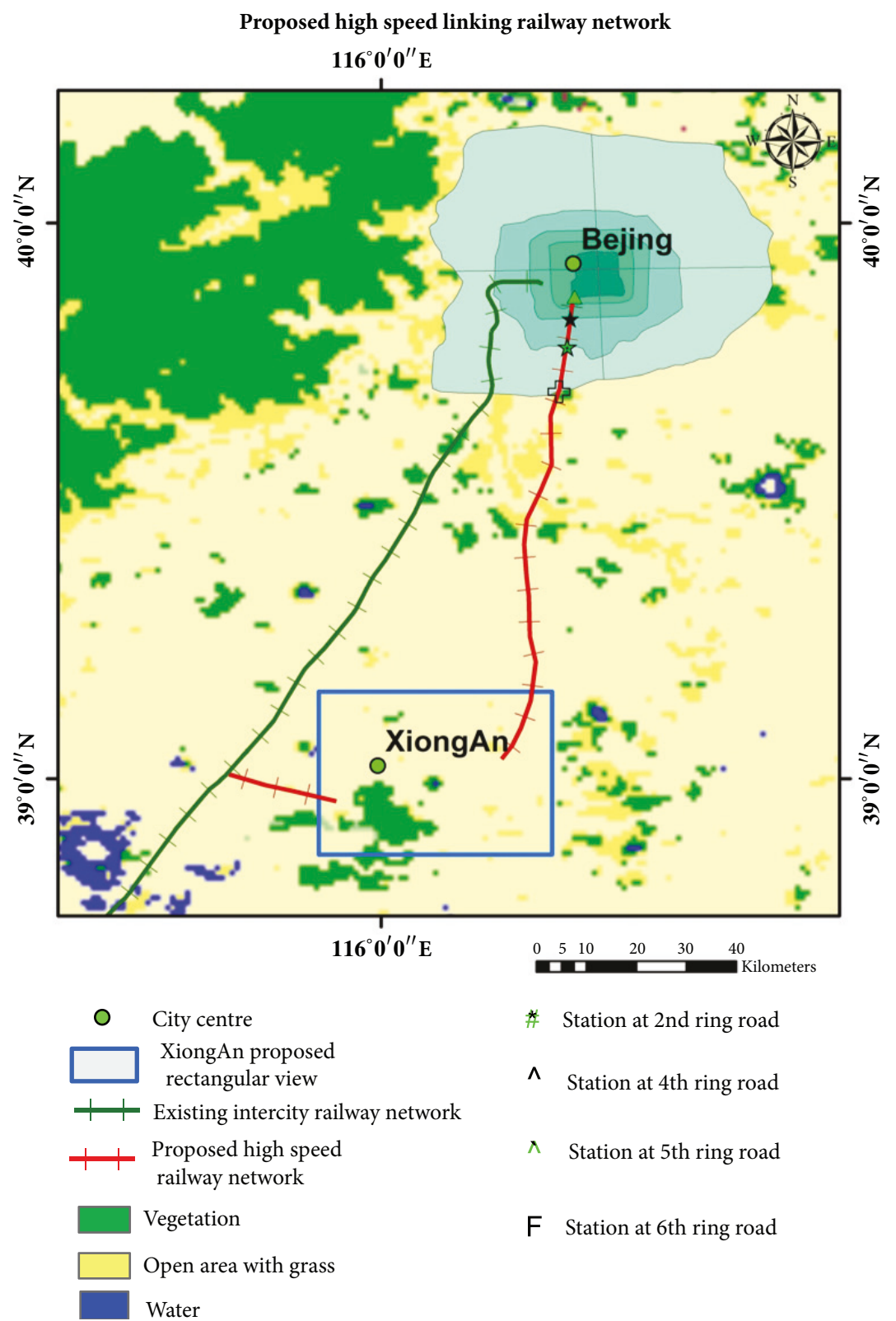

* Station at 2nd ring road

$\wedge$ Station at 4 th ring road

$\wedge$ Station at 5 th ring road

F Station at 6 th ring road

FIGURE 4: Inter-city railway network and proposed high-speed railway line.

Network integration with well-designed transfer stations is a very important parameter for planning the line between Beijing and "XiongAn." Furthermore, the inconvenience of transfers can be overcome by (i) the overall perceived reduction of travel time, (ii) the functional design of lines, (iii) passenger attraction/transit attraction factors to be considered, and (iv) network operating efficiency (Figure 6).

The overall perceived reduction of travel time: Travel time with transfer must be less than travel time by the direct service. People perceive walking and waiting time 2.0 to 2.5 times longer compared to in-vehicle time [80, 81]. Perceived time and not actual clock time should be used for the evaluation of whether or not people will accept the transfers. Functional design of lines: high capacity lines are usually independent lines. Independent networks need efficient transfer and feeder services. Heavy investments are being made worldwide to increase speed on transportation networks. Travel time is of course dependent on distance, but for a given distance, travel on a high-speed dedicated railway line is much faster than the equivalent travel by road [82, 83].

To analyze the $50 \mathrm{~km}$ radius of XiongAn a satellite map was examined as shown in Figure 8. The analysis shows that $75 \%$ of the study area falls below the 1-22 meter elevation category whereas roughly $80 \%$ of slope falls into the category of $0-5 \%$. The land use/land cover classified map derived from Landsat- 8 dataset reveals $62 \%$ of the area falls under urban/settlement/roads categories whereas $37 \%$ area falls 


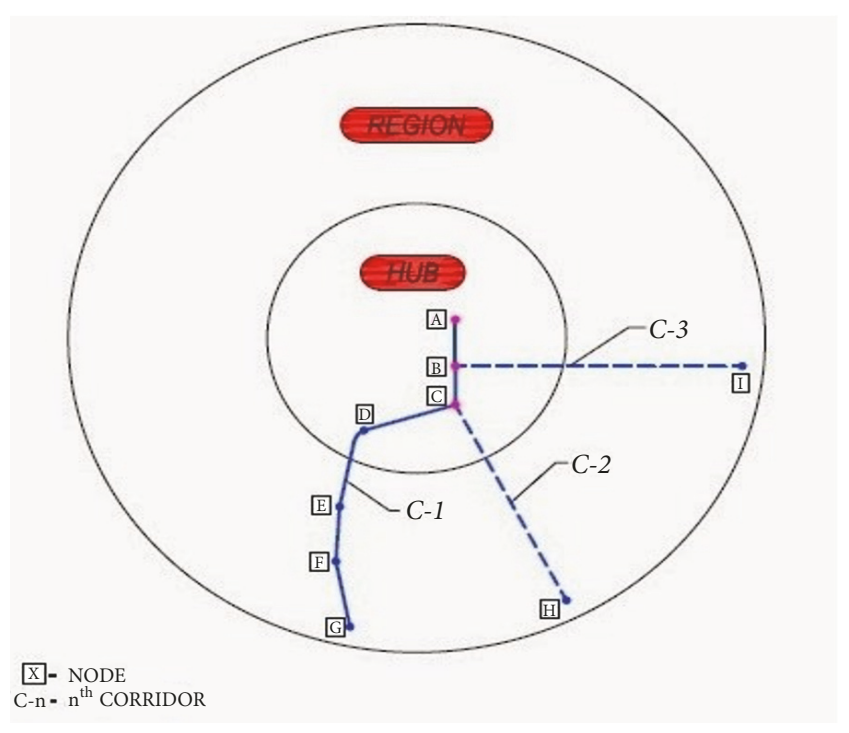

FIGURE 5: Distributed terminal network concept.

under vegetation (forest/agriculture/urban greenery) and contains one percent of all water in the study area.

Step 2 (defining criteria and prioritization route using multicriteria method). The criteria between two cities are evaluated as following:

(i) F1: Cost of travel: This criterion describes the cost of the trip for passengers (ticket price or price of fuel consumption of vehicles when road transport is used).

(ii) F2: Travel time. This includes the time for transportation and change of transport from Beijing to XiongAn.

(iii) F3: Type of infrastructure: This factor shows the category of railway lines and roads. For the railway lines that means high-speed railway or conventional railway; for road transport that means category of road (motorway or railways)

(iv) F4: Connections: This criterion presents the possibilities of connecting with another mode of transport.

(v) F5: Comfort: This shows the convenience of the trip.

(vi) F6: Reliability: This criterion takes into account compliance with the transport timetable, and lack of congestion on highways.

(vii) F7: Level of safety.

(viii) F8: Accessibility: This criterion takes into account the possibilities of passengers obtaining the appropriate mode of transport with convenient connections in transport terminals.

(ix) F9: Type of terminal connection: This criterion presents the type of connection (as shown in Figure 5). (x) F10: Environmentally friendly transport: This means transport with minimal environmental pollution and noise impacts.

In this research five routes and different transport modes connection between Beijing and XiongAn are investigated, taking into account the results of ArcGIS analysis:

(i) V1: Existing intercity railway line. There is no direct railway line existing in the study area; the nearest line is in Baoding.

(ii) V2: Metro and new railway line

(iii) V3: Motorway 1 Beijing to XiongAn

(iv) V4: Motorway 2 Beijing to XiongAn

(v) V5: Motorway 3 Beijing to XiongAn

The existing railway intercity line from Beijing West station passes through rural areas. This line is not specifically connected according to GIS Analytics and online Beijing traffic data. Variants with Motorways 1, 2, and 3 (V3; V4; V5) have overall weak connections because they follow the ring road, which is not integrated. The existing railway line (V1) has good integration with other types of transport, bus, road transport, and subway. Table 1 presents the characteristics of the various options for transportation between Beijing and XiongAn.

The present study uses the AHP methodology to determine what weight should be given to each criterion and to compare the alternatives Super Decision software used [84]. The super decision software is based on the Analytic Hierarchy Process (AHP) and the Analytic Network Process (ANP). The software helps to structure and organize the comparisons, as well as obtaining and analyzing the results. The software also calculates the consistency index (CI) of the judgments and Graphical Sensitivity Analysis.

Figure 9 presents the structure of the model. A hierarchical decision model has a goal, criteria that are evaluated for their importance to the goal, and alternatives that are evaluated for the level of preferences with respect to each criterion (Figure 7). The highest level of the hierarchy is the overall goal: to determine the best connection between Beijing and XiongAn. Under the overall goal, the second level represents ten criteria affecting transport selection. The alternatives for transportation are on the third level.

Pairwise comparison is the process of comparing the relative importance of two criteria with respect to another element (for example, the goal) in the level above to establish priorities for the elements being compared. In this research a group of experts gave an overall score on the scale of Saaty. Table 2 shows the prioritization matrix and the weight given to each criterion by AHP method. The value of consistency ratio $(\mathrm{CI}=0,097)$ is less than 0,1 , according to (A.4) (Appendix) which means that the expert's assessments are adequate.

It is found that factors affecting prioritization of alternatives include travel time $(0,16)$, cost of travel $(0,15)$, level of safety $(0,15)$, reliability $(0,13)$, accessibility $(0,10)$, and environmental protection $(0,10)$ as shown in Figure 8 . 


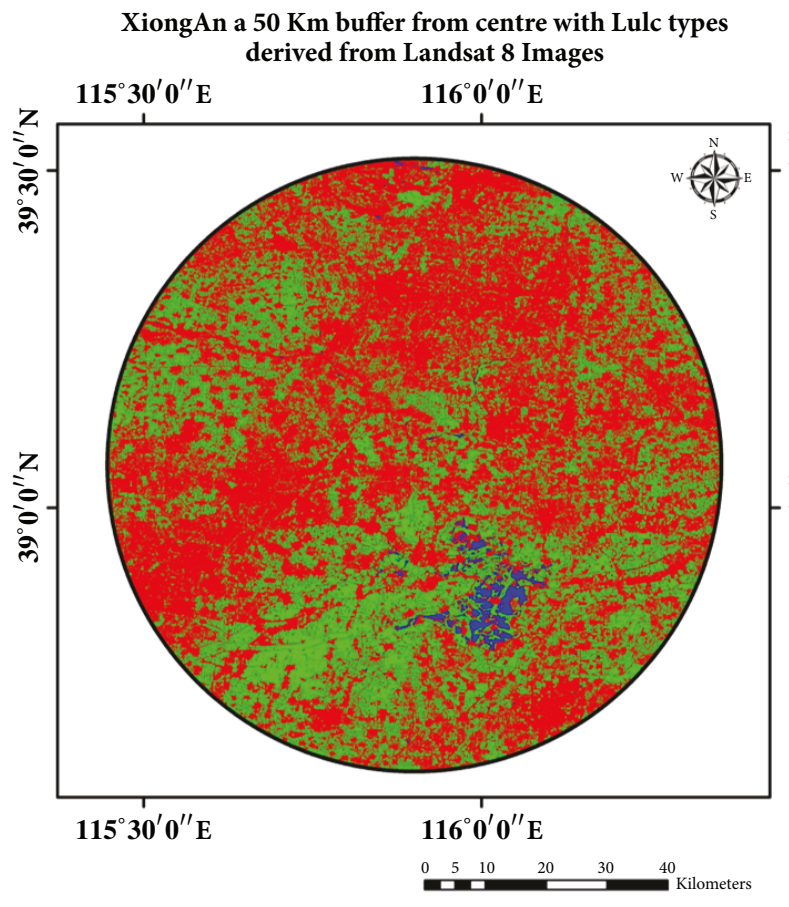

Urban/settlement/roads

Vegetation(forest/agriculture/urban greenery)

Water
XiongAn a $50 \mathrm{Km}$ buffer from centre with digital elevation data derived from ASTER

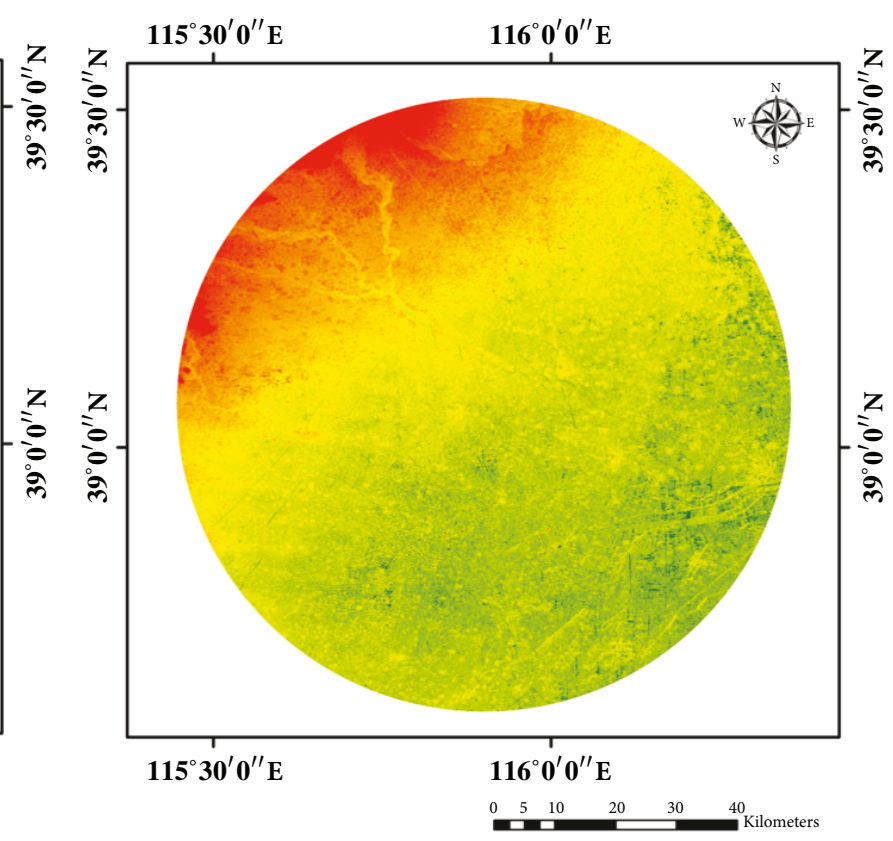

Elevation (meter) from MSL.

$$
\begin{aligned}
& \text { High : } 229 \\
& \text { Low : } 1
\end{aligned}
$$

(b)

(a)

XiongAn a $50 \mathrm{Km}$ buffer from centre with slope data derived from DEM

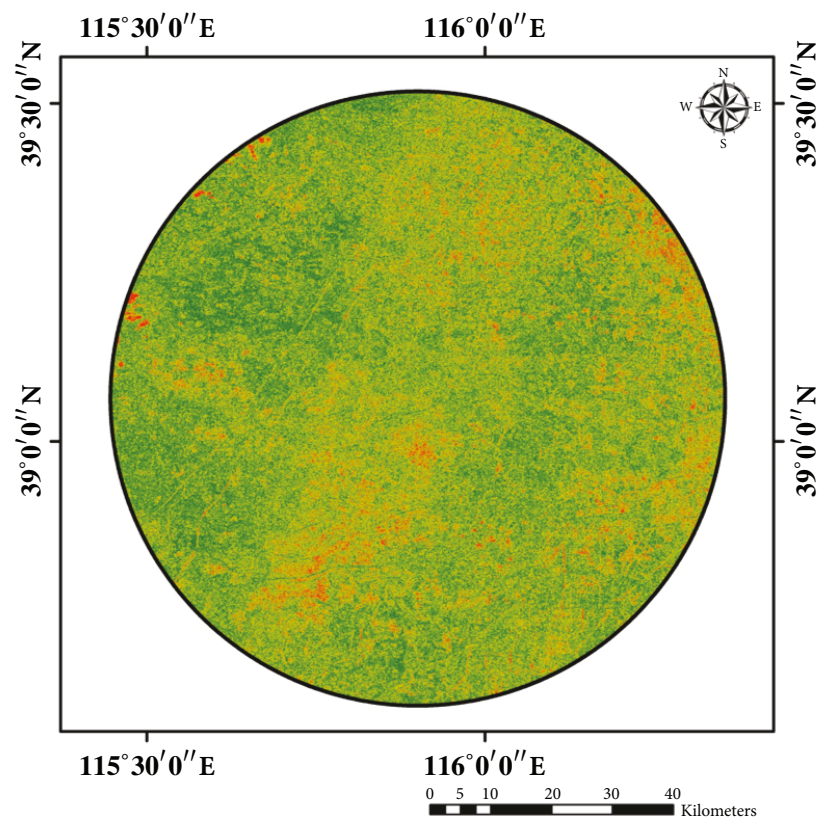

Slope in degree

Value

High : 49

(c)

Figure 6: XiongAn satellite images. 
TABLE 1: Characteristics of variants.

\begin{tabular}{|c|c|c|c|c|c|c|}
\hline & Variant & Length, km & Type of way & Time, $\mathrm{h}$ & Accessibility & $\begin{array}{l}\text { Connection } \\
\text { with another } \\
\text { type of } \\
\text { transport }\end{array}$ \\
\hline V1 & $\begin{array}{c}\text { Existing } \\
\text { intercity } \\
\text { railway line }\end{array}$ & 157 & railway & $\begin{array}{l}3 \mathrm{~h}, 30 \\
\text { minute- } \\
\text { 4hour }\end{array}$ & $\begin{array}{l}\text { no specific } \\
\text { connection }\end{array}$ & $\begin{array}{c}\text { Bus and } \\
\text { Subway, Road }\end{array}$ \\
\hline V2 & New line & 105 & $\begin{array}{c}\text { Metro, } \\
\text { railway } \\
\text { (High-speed } \\
\text { Line) }\end{array}$ & $\begin{array}{l}\text { Should be } \\
\text { less than } 1 \\
\text { hour. }\end{array}$ & $\begin{array}{l}\text { Metro + new } \\
\text { railway line; } \\
\text { connections } \\
\text { in metro } \\
\text { station }\end{array}$ & $\begin{array}{l}\text { Subway } \\
\text { Stations }\end{array}$ \\
\hline V3 & Motorway-1 & 125 & $\begin{array}{l}\text { Trunk road } \\
\text { +Motorway }\end{array}$ & $\begin{array}{l}1 \text { hour, } 48 \\
\text { minute }\end{array}$ & $\begin{array}{c}\text { 6th Ring } \\
\text { Road+ } \\
\text { Motorway } \\
\end{array}$ & $\begin{array}{l}\text { Overall weak } \\
\text { connection }\end{array}$ \\
\hline V4 & Motorway-2 & 167 & $\begin{array}{l}\text { Trunk road } \\
+ \text { Motorway }\end{array}$ & $\begin{array}{l}2 \text { hour } 8 \\
\text { minute }\end{array}$ & $\begin{array}{l}\text { 6th Ring } \\
\text { Road+ } \\
\text { Motorway }\end{array}$ & $\begin{array}{l}\text { Overall weak } \\
\text { connection }\end{array}$ \\
\hline V5 & Motorway-3 & 160 & $\begin{array}{l}\text { Trunk road } \\
+ \text { Motorway }\end{array}$ & $\begin{array}{l}2 \text { hour } 24 \\
\text { minute }\end{array}$ & $\begin{array}{l}\text { 6th Ring } \\
\text { Road+ } \\
\text { Motorway }\end{array}$ & $\begin{array}{c}\text { Overall weak } \\
\text { connection }\end{array}$ \\
\hline
\end{tabular}

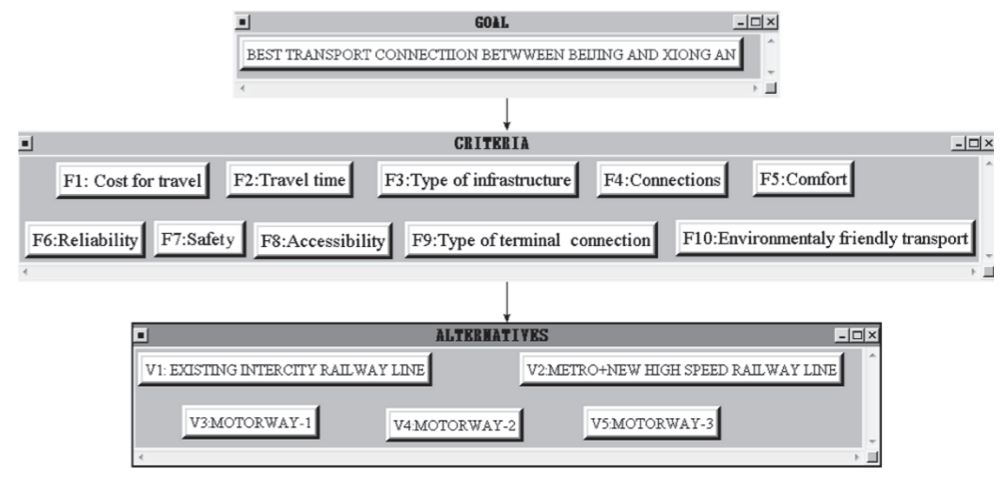

FIGURE 7: AHP hierarchical model for goals, criteria, and alternatives for the study area.

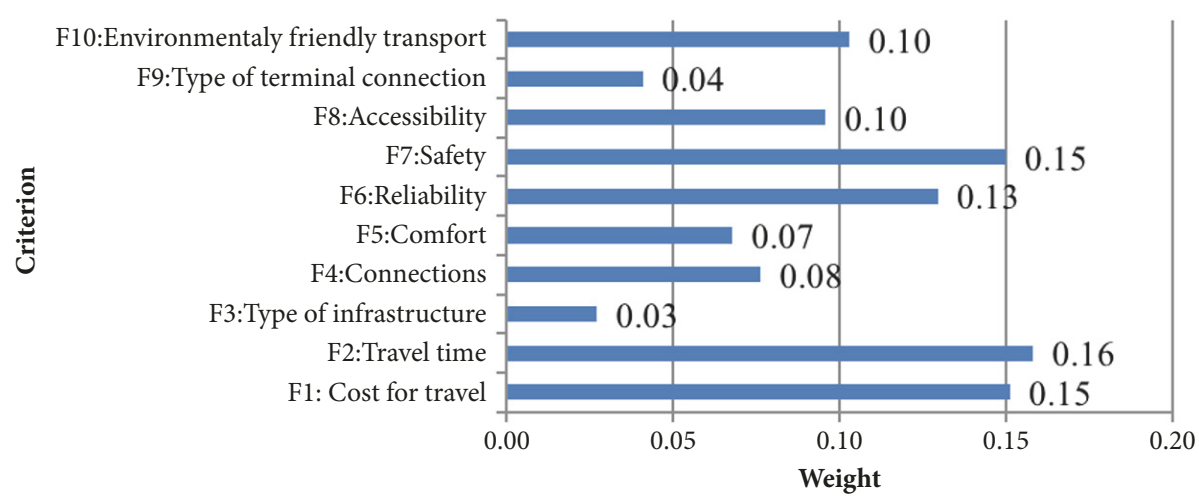

FIGURE 8: Weights of criteria.

Table 3 presents the important intensity levels for evaluating the alternatives. They are rated as excellent, good, above average, average and below average by the level of influence of the criteria. Table 4 shows the evaluation of alternatives by each criterion. The assessment is made using intensity levels.

Figure 9 shows the prioritization of alternatives and priorities. The highest priority is the option of a connection 


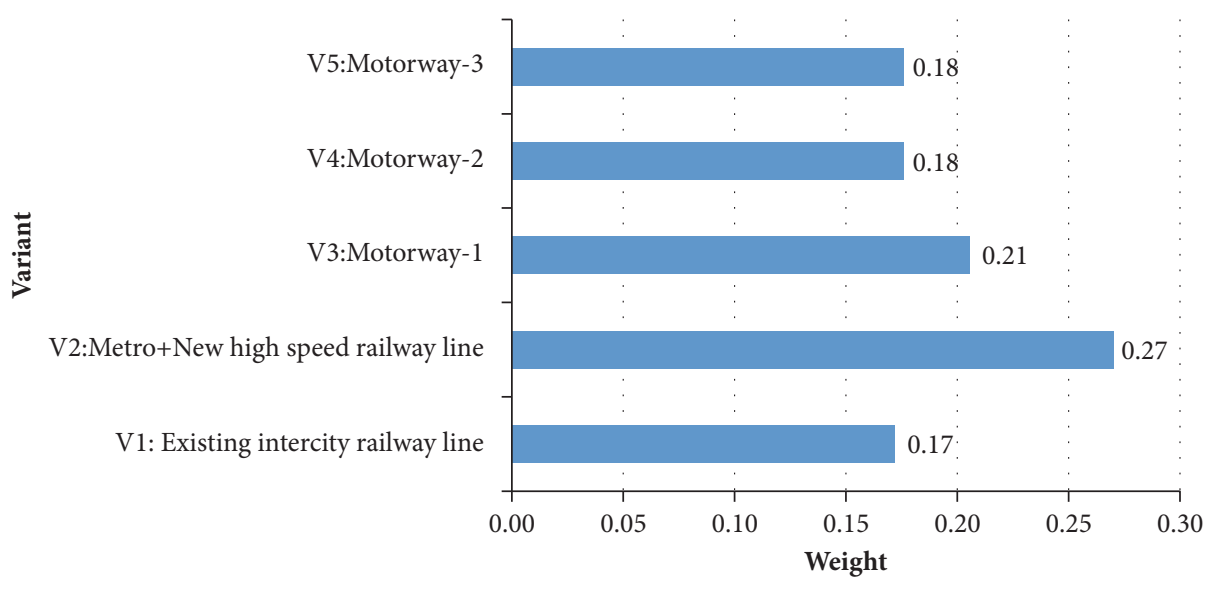

Figure 9: Priorities of alternatives.

TABLE 2: Prioritization matrix of criteria and weights.

\begin{tabular}{|c|c|c|c|c|c|c|c|c|c|c|c|}
\hline Criteria & $\mathrm{F} 1$ & $\mathrm{~F} 2$ & F3 & $\mathrm{F} 4$ & F5 & F6 & F7 & F8 & F9 & F10 & Weight \\
\hline F1: Cost for travel & 1 & $1 / 2$ & 3 & 3 & 2 & 1 & 1 & 4 & 4 & 2 & 0,15 \\
\hline F2: Travel time & 2 & 1 & 5 & 3 & 3 & 1 & 1 & 2 & 2 & 2 & 0,16 \\
\hline F3: Type of infrastructure & $1 / 3$ & $1 / 5$ & 1 & $1 / 3$ & $1 / 3$ & $1 / 4$ & $1 / 4$ & $1 / 3$ & $1 / 3$ & $1 / 3$ & 0,03 \\
\hline F4: Connections & $1 / 3$ & $1 / 3$ & 3 & 1 & $1 / 3$ & $1 / 3$ & $1 / 4$ & 3 & 3 & $1 / 2$ & 0,08 \\
\hline F5: Comfort & $1 / 2$ & $1 / 3$ & 3 & 3 & 1 & $1 / 5$ & $1 / 5$ & $1 / 3$ & 3 & $1 / 2$ & 0,07 \\
\hline F6: Reliability & 1 & 1 & 4 & 3 & 5 & 1 & $1 / 2$ & $1 / 2$ & 3 & 1 & 0,13 \\
\hline F7: Level of safety & 1 & 1 & 4 & 2 & 5 & 2 & 1 & 2 & 2 & 1 & 0,15 \\
\hline F8:Accessibility & $1 / 4$ & $1 / 2$ & 3 & $1 / 3$ & 3 & 2 & $1 / 2$ & 1 & 3 & 1 & 0,10 \\
\hline F9:Type of terminal connection & $1 / 4$ & $1 / 2$ & 3 & $1 / 3$ & $1 / 3$ & $1 / 3$ & $1 / 2$ & $1 / 3$ & 1 & 1 & 0,04 \\
\hline F10:Environmentaly friendly transport & $1 / 2$ & $1 / 2$ & 3 & 2 & 2 & 1 & 1 & 1 & 1 & 1 & 0,10 \\
\hline
\end{tabular}

TABLE 3: Five intensity levels and their corresponding values.

\begin{tabular}{|c|c|c|c|c|c|c|}
\hline Super Decisions Ratings & Excellent & Good & Above Average & Average & Below Average & Score \\
\hline Excellent & 1 & 2 & 3 & 4 & 5 & 0,42 \\
\hline Good & $1 / 2$ & 1 & 2 & 3 & 4 & 0,26 \\
\hline Above Average & $1 / 3$ & $1 / 2$ & 1 & 2 & 3 & 0,16 \\
\hline Average & $1 / 4$ & $1 / 3$ & $1 / 2$ & 1 & 2 & 0,10 \\
\hline Below Average & $1 / 5$ & $1 / 4$ & $1 / 3$ & $1 / 2$ & 1 & 0,06 \\
\hline
\end{tabular}

between Beijing and XiongAn with a new railway high-speed line.

The sensitivity analysis was also carried out to create the various scenarios based on the priority of the selection criteria. Graphical Sensitivity Analysis enables the researcher to adjust priorities to see the effect of changes in judgments on the overall ranking of decision alternatives. The priority ranges from 0.0 to 1.0 on the $x$-axis. The assessment is carried out by increasing and decreasing one of the seven criteria, keeping the others proportionally the same. Moving the dotted line and dragging can give different scenarios of projection changes for the alternatives. Figure 10 gives an example for criterion $\mathrm{F} 1$ of graphical sensitivity analysis. It shows the upper limit of AHP score whereby the optimal solution is retained. The sensitivity analysis is made for all indicators. The results show that alternative 2 largely retains its position as the best scheme. For the best option, the stability intervals for priority ranges for criteria are F1 (0$0.67 \%)$, for all others criteria (0-100\%).

The developed approach could also be applied to assess other transport options. The investigated criteria and their weights could be applied to study transport planning for other megapolises. The model could also to work in the case of introducing additional criteria. In this case, the value of consistency ratio CI should be observed for the adequacy of the expert assessments. The application of GIS helps to form different variants of transport connections and their parameters. For this reason, this approach is appropriate when combined with the AHP method to make decisions. The methodology can also to be used to assess existing 
TABLE 4: Ratings for alternatives.

\begin{tabular}{|c|c|c|c|c|c|c|c|c|c|c|c|}
\hline \multirow{2}{*}{ Alternatives } & \multicolumn{10}{|c|}{ Criteria } & \multirow{2}{*}{ Weigh } \\
\hline & $\mathrm{F} 1$ & $\mathrm{~F} 2$ & F3 & $\mathrm{F} 4$ & F5 & F6 & F7 & F8 & F9 & F10 & \\
\hline V1: & AVG & B-AVG & $\mathrm{G}$ & A-AVG & $\mathrm{G}$ & Good & Good & AA & Good & Good & 0,17 \\
\hline V2: & AVG & ET & ET & ET & ET & ET & ET & ET & ET & ET & 0,27 \\
\hline V3: & $\mathrm{G}$ & G & A-AVG & G & G & Good & $\mathrm{AA}$ & G & G & B- AVG & 0,21 \\
\hline V4: & G & A-AVG & A-AVG & G & AVG & A-AVG & A-AVG & G & A- AVG & B- AVG & 0,18 \\
\hline V5: & $\mathrm{G}$ & A-AVG & A-AVG & G & AVG & A- AVG & A- AVG & $\mathrm{G}$ & A-AVG & B- AVG & 0,18 \\
\hline
\end{tabular}

* Average (AVG), good (G), above average (A-AVG), below average (B-AVG), above Average (A-AVG), and excellent (ET).

TABLE 5: Saaty's scale for pairwise comparison.

\begin{tabular}{lc}
\hline Intensely of importance & Definition \\
\hline 1 & Equal importance \\
\hline 3 & Moderate importance of one factor over another \\
\hline 5 & Strong or essential importance \\
\hline 7 & Very strong importance \\
\hline 9 & Extreme importance \\
\hline $2,4,6,8$ & Values for intermediate comparison \\
\hline
\end{tabular}

transport lines. In this case, GIS analysis could not be used. Furthermore, the future research recommendation may be to extend the study, while considering other important planning parameters, while using other methodologies to help the developer and planner, to understand and analyze which parameters and criteria need to be considered for planning between megapolises.

\section{Conclusion}

This paper presents a multicriteria-based transportation planning for satellite towns of the growing cities. The methodology incorporated an analytic hierarchy process to evaluate various criteria from a set of alternative options from among which the optimal decision was made for the study area. Based on the analysis a railway high-speed line is proposed for the study area. The selection criteria based on cost for travel, travel time, type of infrastructure, connections, comfort, reliability, safety, accessibility, type of terminal connection, and environmental friendly transport was evaluated using an analytic hierarchy process tool. It was found that travel time, cost of travel, safety, reliability, accessibility, and environment are the criteria mainly responsible for selecting the best alternative. The sensitivity analysis also supported the selection of the high-speed railway line with the metro line to cope with transportation demand of the study area. The methodology developed can be used for similar cities by varying the selection criteria factors based on the priorities of the requirements.

The study suggests that application of GIS and Analytic hierarchy process supports making the best decision for transport planning from a multitude of available different options. The results of this study demonstrate that the combination of both methods can serve as a decision support system for the route selection. The proposed methodology can be used in research on transport connections and for other cities.

\section{Appendix}

The result of the pairwise comparison of $\mathrm{n}$ criteria can be summarized in an $(n, n)$ evaluation matrix in which every element $a_{i j}(i, j=1, \ldots, n)$, which serves to determine the weights of the criteria. (see Table 5).

The matrix elements have the following relationships:

$$
\begin{aligned}
& a_{i i}=1 ; \\
& a_{i j} \neq 0 ; \\
& a_{j i}=\frac{1}{a_{i j}}
\end{aligned}
$$

The second step in the AHP procedure is to normalize the matrix. The relative weights are given by the normalized right eigenvector $\left(W=\left\{w_{1}, \ldots, w_{n}\right\}^{T}\right)$ associated with the largest eigenvalue $\left(\lambda_{\max }\right)$ of the square matrix $A$ providing the weighting values for all decision elements. The largest eigenvalue $\left(\lambda_{\max }\right)$ can be calculated using the following:

$$
\begin{aligned}
& A W=\lambda_{\text {max }} \cdot W \\
& \lambda_{\text {max }}=\sum_{i=1}^{n}\left[\left(\sum_{j=1}^{n} a_{i j}\right) \cdot W_{i}\right]
\end{aligned}
$$

The third step calculates the consistency ratio and checks its value.

The consistency ratio is found in the following formula:

$$
C R=\frac{C I}{R I} \leq 0,1
$$




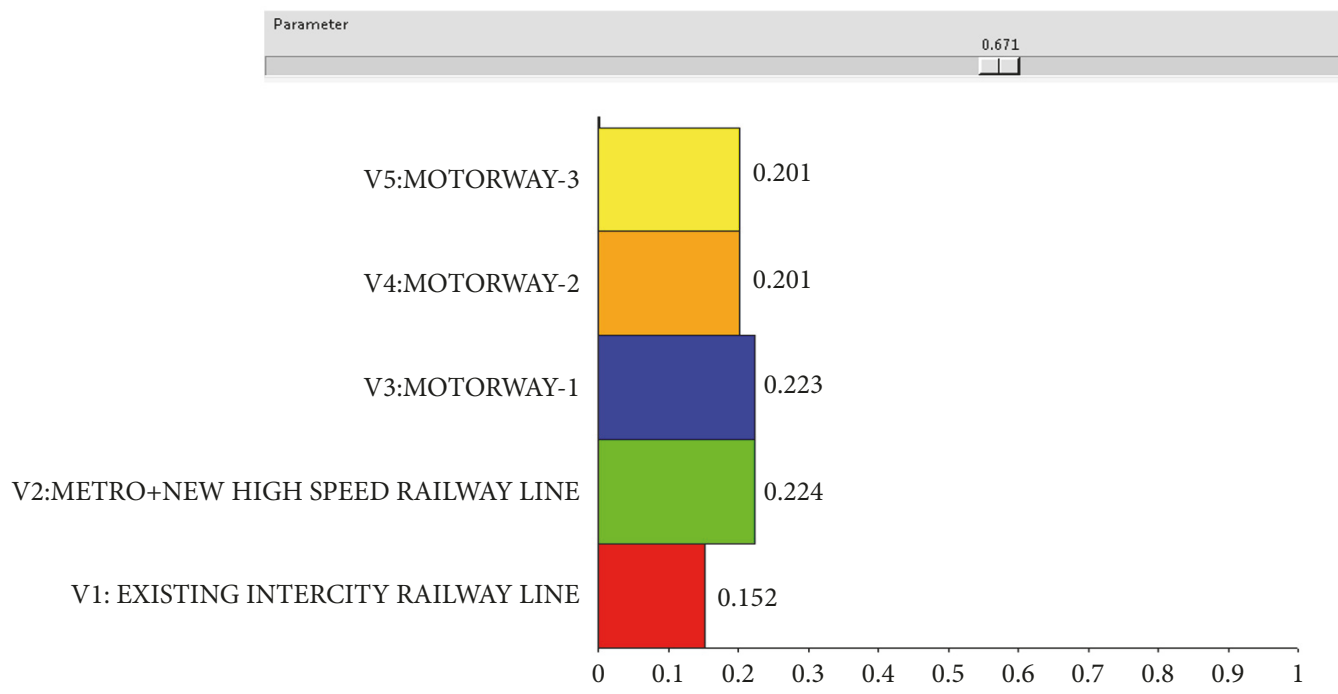

FIGURE 10: Graphical sensitivity analysis for criterion F1.

TABle 6: Random Consistency Index (RI).

\begin{tabular}{|c|c|c|c|c|c|c|c|c|c|c|c|c|c|c|c|}
\hline $\mathrm{n}$ & 1 & 2 & 3 & 4 & 5 & 6 & 7 & 8 & 9 & 10 & 11 & 12 & 13 & 14 & 15 \\
\hline RI & 0 & 0 & 0.58 & 0.9 & 1.12 & 1.24 & 1.32 & 1.41 & 1.45 & 1.49 & 1.51 & 1.48 & 1.56 & 1.57 & 1.59 \\
\hline
\end{tabular}

where $C I$ is the consistency index; $R I$ is a random index. The random matrix is given by Saaty, [8] as shown in Table 2. (see Table 6)

The consistency index is

$$
C I=\frac{\lambda_{\max }-n}{n-1}
$$

The largest eigenvalue $\lambda_{\max }$ is the maximum eigenvalue of the priority matrix, $n$ is the number of elements in the matrix. Generally, if the $C R$ is less than 0.10 , the consistency of the decision-maker is considered satisfactory. But if $C R$ exceeds 0.10 , some revisions of judgments may be required. In order to control the results of the methods, the consistency ratio (CR) is used to estimate directly the consistency of pairwise comparisons.

\section{Conflicts of Interest}

The authors declare that they have no conflicts of interest.

\section{Authors' Contributions}

All authors contributed equally in the preparation of this manuscript and declare no conflict of interest.

\section{Acknowledgments}

The authors gratefully acknowledge the financial support from the National Natural Science Foundation of China under Grant nos. 41702371, 41572274, China Postdoctoral Science Foundation under Grant no. 2016M591078, and the
Fundamental Research Funds for the Central Universities of China under Grant no. FRF-TP-16-014A1.

\section{References}

[1] M. T. Brömmelstroet, M. S. Nicolaisen, B. Büttner, and A. Ferreira, "Experiences with transportation models: An international survey of planning practices," Transport Policy, vol. 58, pp. 10-18, 2017.

[2] D. Banister, "The sustainable mobility paradigm," Transport Policy, vol. 15, no. 2, pp. 73-80, 2008.

[3] D. Banister, Unsustainable Transport-City Transport in the New Century, Taylor and Francis Ltd, 1st edition, 2005.

[4] W. Mo, Y. Wang, Y. Zhang, and D. Zhuang, "Impacts of road network expansion on landscape ecological risk in a megacity, China: A case study of Beijing," Science of the Total Environment, vol. 574, pp. 1000-1011, 2017.

[5] M. T. Simmons, H. C. Venhaus, and S. Windhager, "Exploiting the attributes of regional ecosystems for landscape design: The role of ecological restoration in ecological engineering," Ecological Engineering, vol. 30, no. 3, pp. 201-205, 2007.

[6] J. Li and Z. Zhou, "Coupled analysis on landscape pattern and hydrological processes in Yanhe watershed of China," Science of the Total Environment, vol. 505, pp. 927-938, 2015.

[7] T. B. Joewono and H. Kubota, "Safety And Security Improvement in Public Transportation Based on Public Perception in Developing Countries," IATSS Research, vol. 30, no. 1, pp. 86100, 2006.

[8] B. Bevrani, R. L. Burdett, A. Bhaskar, and P. K. Yarlagadda, "A capacity assessment approach for multi-modal transportation systems," European Journal of Operational Research, vol. 263, no. 3, pp. 864-878, 2017.

[9] Y. Wang, S. Mishra, X. Ye, L. Li, and B. Wu, “The Application of Integrated Multimodal Metropolitan Transportation Model in 
Urban Redevelopment for Developing Countries," in Proceedings of the World Conference on Transport Research - WCTR 2016, pp. 2990-3002, Shanghai, China, 2017.

[10] M. Song, G. Zhang, W. Zeng, J. Liu, and K. Fang, "Railway transportation and environmental efficiency in China," Transportation Research Part D: Transport and Environment, vol. 48, pp. 488-498, 2016.

[11] Z. Zhu, A. Zhang, and Y. Zhang, "Connectivity of Intercity Passenger Transportation in China: A Multi-Modal and Network Approach," Journal of Transport Geography, 2017.

[12] J. Wang, C. Wang, J. Lv, Z. Zhang, and C. Li, "Modeling Travel Time Reliability of Road Network Considering Connected Vehicle Guidance Characteristics Indexes," Journal of Advanced Transportation, vol. 2017, Article ID 2415312, 9 pages, 2017.

[13] R. B. Noland and J. W. Polak, "Travel time variability: a review of theoretical and empirical issues," Transport Reviews, vol. 22, no. 1, pp. 39-54, 2002.

[14] H. X. Liu, X. He, and W. Recker, "Estimation of the timedependency of values of travel time and its reliability from loop detector data," Transportation Research Part B: Methodological, vol. 41, no. 4, pp. 448-461, 2007.

[15] R. L. Burdett and E. Kozan, "Techniques for absolute capacity determination in railways," Transportation Research Part B: Methodological, vol. 40, no. 8, pp. 616-632, 2006.

[16] R. L. Burdett, "Multi-objective models and techniques for analysing the absolute capacity of railway networks," European Journal of Operational Research, vol. 245, no. 2, pp. 489-505, 2015.

[17] B. Bevrani, R. L. Burdett, and P. K. Yarlagadda, "A Case Study of The Iranian National Railway And Its Absolute Capacity Expansion Using Analytical Models," Transport, vol. 32, no. 4, pp. 1-17, 2017.

[18] S. Wang, L. Sun, J. Rong, S. Hao, and W. Luo, “Transit trip distribution model considering land use differences between catchment areas," Journal of Advanced Transportation, vol. 50, no. 8, pp. 1820-1830, 2016.

[19] F. Zheng, X. Liu, H. V. Zuylen, J. Li, and C. Lu, “Travel Time Reliability for Urban Networks: Modelling and Empirics," Journal of Advanced Transportation, vol. 2017, Article ID 9147356, 13 pages, 2017.

[20] F. Dobruszkes, "High-speed rail and air transport competition in Western Europe: a supply-oriented perspective," Transport Policy, vol. 18, no. 6, pp. 870-879, 2011.

[21] R. T. T. Forman, "Estimate of the area affected ecologically by the road system in the United States," Conservation Biology, vol. 14, no. 1, pp. 31-35, 2000.

[22] L. Shuangcheng, X. Yueqing, Z. Qiaofu, and W. Lei, "Statistical Analysis on the Relationship between Road Network and Ecosystem Fragmentation in China," Progress In Geography, 2004, http://en.cnki.com.cn/Article_en/CJFDTOTALDLKJ200405009.htm.

[23] J. Chai, Q.-Y. Lu, S.-Y. Wang, and K. K. Lai, "Analysis of road transportation energy consumption demand in China," Transportation Research Part D: Transport and Environment, vol. 48, pp. 112-124, 2016.

[24] X. Hu, S. Chang, J. Li, and Y. Qin, "Energy for sustainable road transportation in China: Challenges, initiatives and policy implications," Energy, vol. 35, no. 11, pp. 4289-4301, 2010.

[25] R. T. T. Forman and L. E. Alexander, "Roads and their major ecological effects," Annual Review of Ecology, Evolution, and Systematics, vol. 29, pp. 207-231, 1998.
[26] X. Yan and R. J. Crookes, "Energy demand and emissions from road transportation vehicles in China," Progress in Energy and Combustion Science, vol. 36, no. 6, pp. 651-676, 2010.

[27] S. Zhang and B. Lin, "Investigating the rebound effect in road transport system: Empirical evidence from China," Energy Policy, vol. 112, pp. 129-140, 2018.

[28] Z. Luo, G. Wan, C. Wang, and X. Zhang, "Urban pollution and road infrastructure: A case study of China," China Economic Review, vol. 49, pp. 171-183, 2018.

[29] B. Jiang, S. Liang, Z.-R. Peng et al., "Transport and public health in China: the road to a healthy future," The Lancet, vol. 390, no. 10104, pp. 1781-1791, 2017.

[30] J. Chen, F. Zhao, Z. Liu, X. Ou, and H. Hao, "Greenhouse gas emissions from road construction in China: A province-level analysis," Journal of Cleaner Production, vol. 168, pp. 1039-1047, 2017.

[31] B. Luin, S. Petelin, and F. Al Mansour, "Modeling the impact of road network configuration on vehicle energy consumption," Energy, vol. 137, pp. 260-271, 2017.

[32] Z. Li, M. Wu, and B. R. Chen, "Is road infrastructure investment in China excessive? Evidence from productivity of firms," Regional Science \& Urban Economics, vol. 65, pp. 116-126, 2017.

[33] S. L. Liu, B. S. Cui, S. K. Dong, Z. F. Yang, M. Yang, and K. Holt, "Evaluating the influence of road networks on landscape and regional ecological risk-A case study in Lancang River Valley of Southwest China," Ecological Engineering, vol. 34, no. 2, pp. 91-99, 2008.

[34] A. Farooq, M. Xie, E. J. Williams, V. K. Gahlot, D. Yan, and Z. Yi, "Downsizing Strategy for Cars, Beijing for People Not for Cars: Planning for People," Periodica Polytechnica Transportation Engineering, vol. 46, no. 1, p. 50, 2017.

[35] Y. Xie, J. Gong, P. Sun, X. Gou, and Y. Xie, "Impacts of major vehicular roads on urban landscape and urban growth in an arid region: A case study of Jiuquan city in Gansu Province, China," Journal of Arid Environments, vol. 127, pp. 235-244, 2016.

[36] L. D. Redon, I. L. Viol, F. Jiguet, N. Machon, O. Scher, and C. Kerbiriou, "Road network in an agrarian landscape: Potential habitat, corridor or barrier for small mammals?" Acta Oecologica, vol. 62, pp. 58-65, 2015.

[37] J. Fan, J. Li, Z. Quan, X. Wu, L. Hu, and Q. Yang, "Impact of road construction on giant panda's habitat and its carrying capacity in Qinling Mountains," Acta Ecologica Sinica, vol. 31, no. 3, pp. 145-149, 2011.

[38] M. Karlson, U. Mörtberg, and B. Balfors, "Road ecology in environmental impact assessment," Environmental Impact Assessment Review, vol. 48, pp. 10-19, 2014.

[39] A. Farooq, M. Xie, E. J. Williams, V. K. Gahlot, D. Yan, and Z. Yi, "Integrated Planning Model for Safe and Sustainable Transportation Development in Beijing, China," in Proceedings of the International Conference on Material Science and Environment Protection, Nanjing, China, 2017, http://dpiproceedings.com/index.php/dtmse/article/view/10874.

[40] J. P. Rodrigue, "The Route Selection Process," The Geography of Transport Systems, 2017, https://people.hofstra.edu/geotrans/ eng/methods/ch2m2en.html.

[41] R. E. Burns, "Transport Planning: Selection of Analytical Techniques," Journal of Transport Economics and Policy, vol. 113, no. 3, pp. 306-321, 1969, http://www.bath.ac.uk/e-journals/jtep/ pdf/Volume_111_No_3_306-321.pdf.

[42] K. Tanczos and A. Torok, "Linear optimization model of urban areas operating efficiency," Transport, vol. 23, no. 3, pp. 225-228, 2007. 
[43] Geography and Geoinformation Science (GGS), George Mason University, http://cos.gmu.edu/ggs/research/.

[44] X. Hu, Z. Wu, C. Wu et al., "Effects of road network on diversiform forest cover changes in the highest coverage region in China: An analysis of sampling strategies," Science of the Total Environment, vol. 565, pp. 28-39, 2016.

[45] S. Y. Chang, W. Vizuete, A. Valencia et al., "A modeling framework for characterizing near-road air pollutant concentration at community scales," Science of the Total Environment, vol. 538, pp. 905-921, 2015.

[46] Z. Guo, D. Hu, F. Zhang, G. Huang, and Q. Xiao, "An integrated material metabolism model for stocks of urban road system in Beijing, China," Science of The Total Environment, vol. 470-471, pp. 883-894, 2014.

[47] J. A. Black, A. Paez, and P. A. Suthanaya, "Sustainable Urban Transportation Performance Indicators and Some Analytical Approaches," Journal of Urban Planning and Development, vol. 128, no. 4, pp. 184-209, 2002.

[48] M. Jakimavicius, "A Gis Based Urban Transport System Analysis And Ranking in Transportation Zones of Vilnius City," in Proceedings of the 7th International Conference, Faculty of Environmental Engineering, Vilnius Gediminas Technical University, Vilnius, Lithuania, 2008, http://citeseerx.ist.psu.edu/ viewdoc/download?doi=10.1.1.604.4808\&rep=rep1\&type $=$ pdf.

[49] H. J. Mille and S. L. Shaw, Geographic Information Systems for Transportation : Principles and Applications, Oxford University Press, 2001, http://library.wur.nl/WebQuery/clc/1860454.

[50] M. M. Hamed and S. M. Easa, "Integrated modeling of urban shopping activities," Journal of Urban Planning Development, vol. 124, no. 3, pp. 115-131, 1998.

[51] Z. Xie and J. Yan, "Kernel Density Estimation of traffic accidents in a network space," Computers, Environment and Urban Systems, vol. 32, no. 5, pp. 396-406, 2008.

[52] R. Liu, Z.-Q. Zhang, W.-M. Li, and C. Zhou, "Determination of four components in Forsythia suspensa from different habitats and different processed products by HPLC," Chinese Journal of Experimental Traditional Medical Formulae, vol. 17, no. 14, pp. 83-86, 2011.

[53] S. A. Fleming, Commuter Rail: Many Factors Influence Liability and Indemnity Provisions, and Options Exist to Facilitate Negotiations, DIANE Publishing, 2009, http://www.ebooksdb.org/ reading/GB2C1A30165CG4GEGD16G669/Commuter-RailMany-Factors-Influence-Liability-And-Indemnity-ProvisionsAnd-Opt.

[54] R. Warren, Rail and the City "Shrinking Our Carbon Footprint While Reimagining Urban Space", Urban and Industrial Environments, The MIT Press, 2014, https://mitpress.mit.edu/ books/rail-and-city.

[55] M. D. Meyer, Transportation Planning Handbook, John Wiley \& Sons, 4th edition, 2016, http://as.wiley.com/WileyCDA/ WileyTitle/productCd-1118762355.html.

[56] T. Saaty, The Analytic Hierarchy Process, Revised editions, Paperback (1996, 2000), McGraw Hill, New York, USA, International, RWS Publications, Pittsburgh, PA, USA, 1980.

[57] T. L. Saaty, "Fundamentals of the analytic network process Dependence and feedback in decision-making with a single network," Journal of Systems Science and Systems Engineering, vol. 13, no. 2, pp. 129-157, 2004.

[58] R. W. Saaty, "Decision Making in Complex Environments (The Analytic Network Process (ANP) for Dependence And Feedback)," https://superdecisions.com/sd_resources/v28_man02 .pdf, 2016.
[59] T. L. Saaty, "Decision making with the analytic hierarchy process," International Journal of Services Sciences, vol. 1, no. 1, pp. 83-98, 2008, https://www.colorado.edu/geography/leyk/ geog_5113/readings/saaty_2008.pdf.

[60] Z. Wang, J. Chen, W. Zheng, and X. Deng, "Dynamics of land use efficiency with ecological intercorrelation in regional development," Landscape and Urban Planning, vol. 177, pp. 303316, 2018.

[61] Z. Shao, The New Urban Area Development (A Case Study in China), Springer, Verlag, Berlin, Heidelberg, Germany, 2015.

[62] L. Qin, "Xiong'an New District?: An old idea is finally accepted," China Dialogue, https://www.chinadialogue.net/culture/9937Xiong-an-New-District-An-old-idea-is-finally-accepted/en, 2017.

[63] Xinhua, "China to create Xiongan New Area in Hebei," Xinhuanet News, http://www.hxen.com/englishnews/nation/201704-02/463436.html, 2017.

[64] Chinadaily, Central Government to Further Shift Non-Essential Functions Out of Beijing, China Daily Beijing Municipal, China, 2017, http://www.chinadaily.com.cn/beijing/2015-02/16/ content_19602930.htm\#.

[65] News, Authoritative experts talk about the new area: Essentially, the country's deputy (权威专家谈雄安新区: 本质 上就是国家副都), 凤凰新媒体 (Phoenix New Media) and Southern Weekend, http://finance.ifeng.com/a/20170404/ 15283145_0.shtml, (Report in Chinese), 2017.

[66] O. Nagai, China to Build Massive City Southwest of Beijing, Nikkei Asian Review, 2017, https://asia.nikkei.com/PoliticsEconomy/Policy-Politics/China-to-build-massive-city-southwest-of-Beijing.

[67] Wang, The State Council Decided to Establish a New Area of Hebei (国务院决定设立河北雄安新区), 新华社 (Xinhua News Agency), 2017, http://news.xinhuanet.com/politics/ 2017-04/01/c_1120741571.htm, (Report in Chinese).

[68] baidu, City Road Grade (CJJ37-2012) Road Code, Baidu Database, 2012, https://max.book118.com/html/2015/0829/24260678 .shtm.

[69] Cheng, Classification Basis of Highway Grade (in Chinese), Baidu Database Library, 2014, https://wenku.baidu.com/view/ 047d2de965ce050876321367.html.

[70] Cheng, Technical Parameters of Highways at All Levels, Baidi Library Database, 2015, https://wenku.baidu.com/view/ 4ae4e45d192e45361166f546.html, (Report in Chinese).

[71] Z. Ying, "Residents/ Activity-travel Behavior Variation by Communities in Beijing, China," Chinese Geographical Science, vol. 23, no. 4, pp. 492-505, 2013.

[72] Schweiz, Swissmetro Network 2005.png, Bernese media, Swissmetro, Switzerland, 2007, http://schweiz.wikia.com/wiki/Datei: Swissmetro_Network_2005.png, (Report in German Language).

[73] Bahn, Die drei Zentralschweizer Projekte Herzstücke der «Bahn 2030», Bahn, Sekretariat ZRK Switzerland, 2009, https://www .zrk.ch/fileadmin/dateien/dokumente/parl-treffen_2009/Positionspapier_f_n.pdf, (Article in German Languague).

[74] P. Schneeberger, In einer Stunde von Zürich nach Lausanne," Nueu Zurcher Zeitung (Newspaper), 2010, https://www.nzz.ch/ in_einer_stunde_von_zuerich_nach_lausanne-1.5504033, (Report in German Language).

[75] Statista, Residential population of the city of Munich in 2016, by age group, The Statistics Portal, 2016, https://www.statista.com/ statistics/519723/munich-population-by-age-group/. 
[76] T. Wolf, Munich Population 2017, World Population Review, 2017, http://worldpopulationreview.com/world-cities/munichpopulation/.

[77] L. München, Mobilität in Deutschland (MiD), Alltagsverkehr in München, landeshauptstadt münchen referat für stadtplanung und bauordnung, Munich, Germany, 2008, http://docplayer .org/30734542-Mobilitaet-in-deutschland-mid-alltagsverkehrin-muenchen-im-muenchner-umland-und-im-mvv-verbundraum.html, (Report in German Language).

[78] MVG, Munich Transport Corporation, Münchner Verkehrsgesellschaft (MVG), 2014, https://www.mvg.de/dam/mvg/ueber/ unternehmensprofil/mvg-image-englisch-s.pdf.

[79] T. Mazzella, Prioritizing Public Transit for Speed, Reliability, and Rider Satisfaction, Urban and Regional Policy, 2013, http:// www.gmfus.org/publications/prioritizing-public-transit-speedreliability-and-rider-satisfaction.

[80] Y. Fan, A. Guthrie, and D. Levinson, "Perception of Waiting Time at Transit Stops and Stations Effects of basic amenities, gender, and security," Transportation Research Part A: Policy and Practice, vol. 88, pp. 251-264, 2016.

[81] H. Iseki, B. D. Taylor, and M. Miller, The Effects of Outof-Vehicle Time on Travel Behavior: Implications for Transit Transfers, California Department of Transportation, Division of Research and Innovation, California, USA, 2006, https://www .its.ucla.edu/wp-content/uploads/sites/6/2014/06/Appendix-A .pdf.

[82] O. Fröidh, "Design speed for new high-speed lines," Journal of Rail Transport Planning \& Management, vol. 4, no. 3, pp. 59-69, 2014.

[83] S. L. Sogin, Y. C. Lai, C. T. Dick, and C. P. Barkan, "Analyzing the Incremental Transition from Single to Double Track Railway Lines," Proceedings of the Institution of Mechanical Engineers, Part F: Journal of Rail and Rapid Transit, vol. 230, no. 8, 2015.

[84] T. L. Saaty, Super Decision Software Implementation Technique along with Analytic Hierarchical Process (AHP) And The Analytic Network Process (ANP), Creative Decisions Foundation, 2017, http://www.superdecisions.com. 


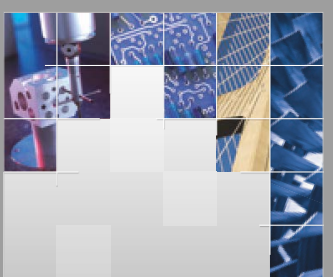

\section{Enfincering}
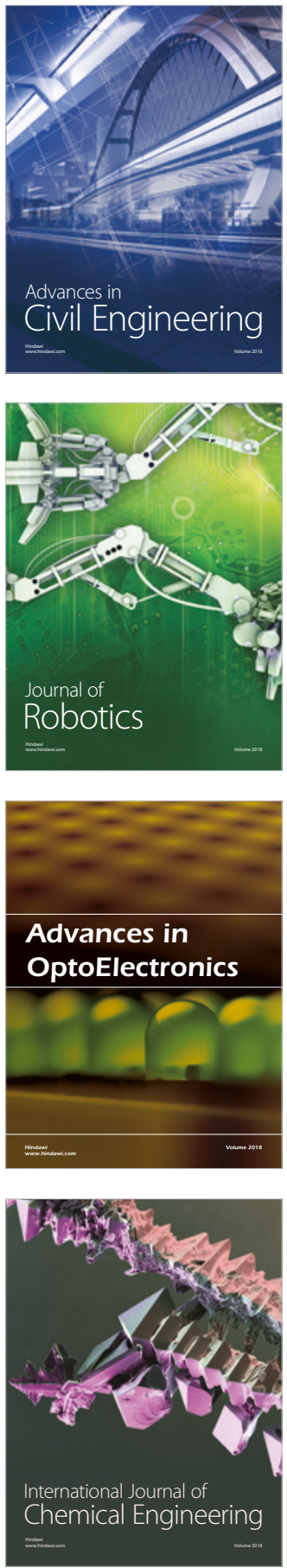

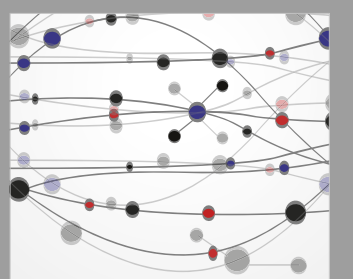

\section{Rotating \\ Machinery}

The Scientific World Journal

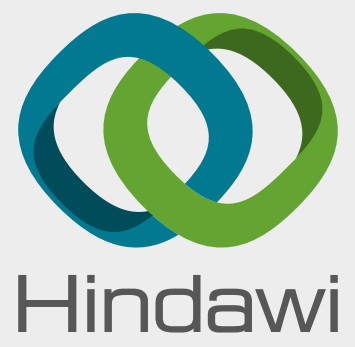

Submit your manuscripts at

www.hindawi.com
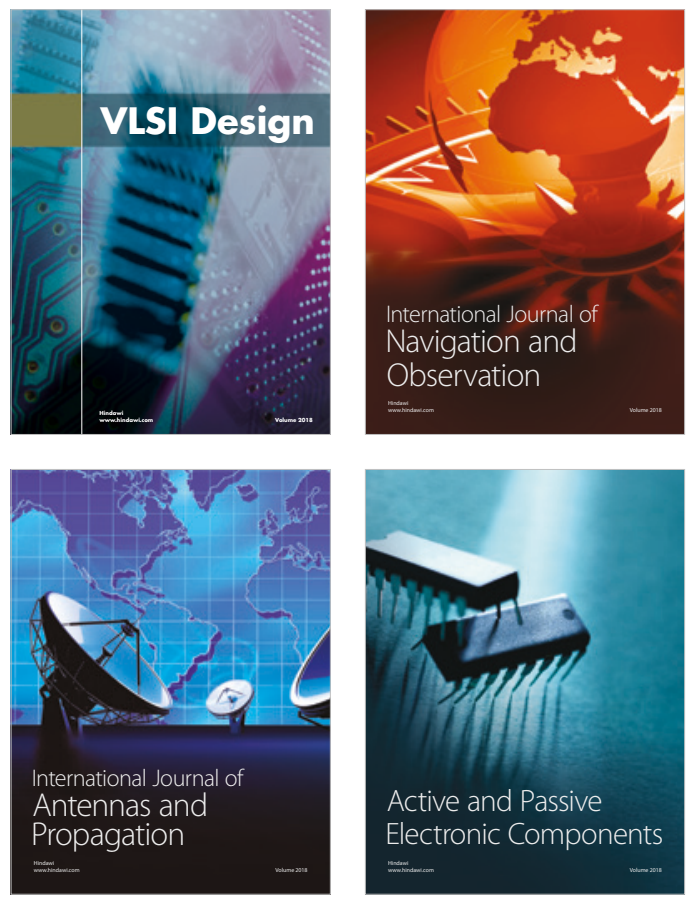
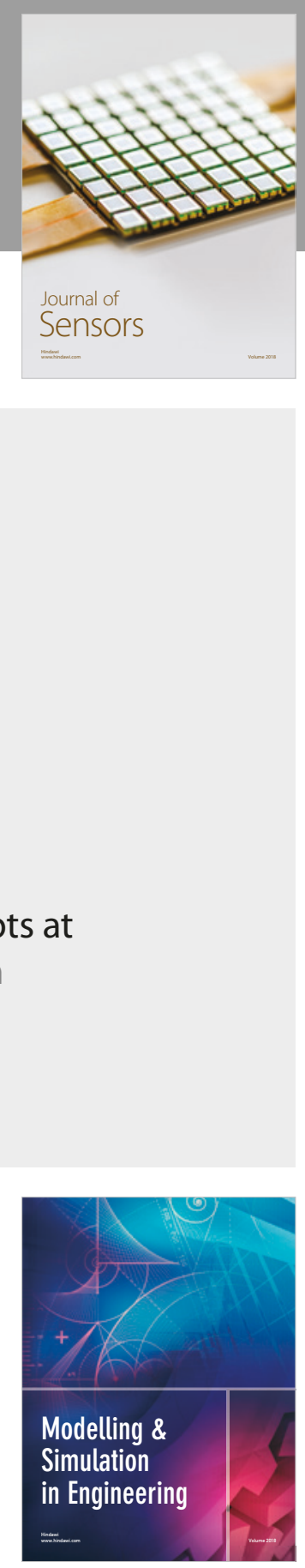

\section{Advances \\ Multimedia}
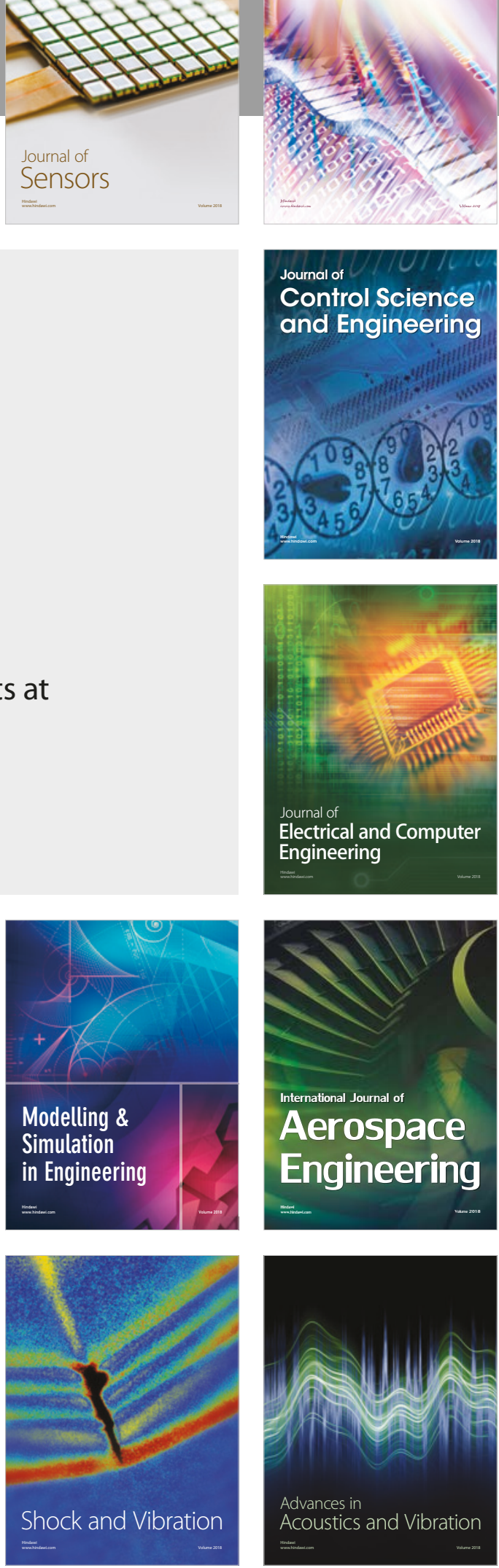